\title{
Experimental therapy of graft-versus-host disease by mesenchymal stromal cells grown on oxide nanocoatings
}

\author{
A.N. Goltsev ${ }^{1}$, I.V. Rassokha ${ }^{1}$, T.G. Dubrava ${ }^{1}$, L.V. Ostankova ${ }^{1}$, \\ M.V. Ostankov', V.I. Safonov ${ }^{2}$, A.V. Zykova ${ }^{2}$ \\ ${ }^{1}$ Institute for Problems of Cryobiology and Cryomedicine of the National Academy of Sciences, Kharkiv; \\ ${ }^{2}$ National Science Center 'Kharkov Institute of Physics and Technology' of the National Academy of \\ Sciences, Kharkiv; e-mail: cryopato@gmail.com
}

\begin{abstract}
Immune aggression to transplanted allogeneic bone marrow, i.e. the graft-versus-host disease (GVHD), could be decreased by the suppression of effector and/or activation of T-regulatory cells (Treg). This task could be solved by co-transplantaiton of allogeneic bone marrow and mesenchymal stromal cells (MSCs). This study demonstrated the elevated immune modulating activity of MSCs by their culturing in vitro on $\mathrm{Al}_{2} \mathrm{O}_{3}$ oxide nanocoatings. Introduction of the cells to the animals with GVHD resulted in an increased content of Treg in the spleen of bone marrow recipients, reduced severity of the pathology, and higher survival of animals. The findings could be the basis for developing the new approaches to optimize the GVHD treatment methods involving the oxide nanocoating cultured MSCS.

Key words: nanocoatings; mesenchymal stromal cells; graft-versus-host disease.
\end{abstract}

\section{INTRODUCTION}

Rapidly developing research in cell and tissue engineering requires the introduction of the new techniques and methods, including the use of different nanomaterials $[1,2]$. It has been shown recently that the functional state of cells could be controlled by modifying the surface of nanocomposite coatings whereon they are cultured [3], but the data on mesenchymal stromal cells (MSCs) are quite scanty. The use of MSCs cultured on nanocoatings in clinical practice, in particular in treatment of the graftversus-host disease (GVHD), could be very prospective.

Studies on decoding the mechanisms of GVHD and its treatment have remained relevant till now. One of the methodological approaches to solve this task is co-transplantation of bone marrow and MSCs [4]. The MSCs are known to have a high potential of self-renewal and the ability to multilineage differentiation [5]. This functional status of MSCs is implemented both in vitro and in vivo during their migration and subsequent regeneration of the recipient damaged sites.

The results of experimental $[6,7]$ and clinical investigations [8] have shown that MSCs have a pronounced immune modulatory potential, which is associated with production of 2,3-dioxygenase indolamine (IDO). The main function of this enzyme is to trigger kynurenine pathway of tryptophan catabolism, resulting in the formation of its decay products in the form of kynurenine, quinoline, picolinic and 3-hydroxyanthranilic acids [9]. These tryptophan catabolites are able of activating the immune suppressive link, particularly, regulatory $\mathrm{T}$ cells [10]. The IDO-dependent immunosuppression is known to be is more inherent to human MSCs. However, there are the reports including our own, indicating the absence of immunosuppression of MSCs when using 1-methyl tryptophan as an inhibitor of IDO in the model of GVHD in mice $[11,12]$.

Within the frames of the STCU project \# 4974 we have studied the mechanisms of action of oxide nanocomposite coatings $\left(\mathrm{Al}_{2} \mathrm{O}_{3}\right.$, (C) A.N. Goltsev, I.V. Rassokha, T.G. Dubrava, L.V. Ostankova, M.V. Ostankov, V.I. Safonov, A.V. Zykova 
$\mathrm{Ta}_{2} \mathrm{O}_{5}, \mathrm{ZrO}_{2}$ ) with different micro-architecture on regulation of functional status MSCs [13]. Goltsev AN. et al. [7] have found that the coating of $\mathrm{Al}_{2} \mathrm{O}_{3}$ contributed to the maximum cell adhesion and selective enrichment of bone marrow culture with the cells expressing markers of MSCs (CD44, CD73, CD105, CD106) and increase in the expression rate of ido gene, responsible for the synthesis of the IDO enzyme even at the second passage.

The established fact of the increased ido gene expression in MSCs after culturing on $\mathrm{Al}_{2} \mathrm{O}_{3}$ coating suggests the possibility of more effective treatment of the GVHD. Based on the above, the purpose of this study was to investigate the immunocorrecting effect in therapy of experimental GVHD rendered by MSCs with a functional potential altered during culturing on $\mathrm{Al}_{2} \mathrm{O}_{3}$ nanocoating.

\section{METHODS}

The studies were carried out in 20-week-old $\mathrm{CBA} / \mathrm{H}$ and (CBA/HxC57B1)F1 mice weighing 24-26 $\mathrm{g}$ in accordance with the General Principles of Experiments in Animals approved by the $5^{\text {th }}$ National Congress in Bioethics (Kiev, 2013) compliant with the statements of European Convention for the Protection of Vertebrate Animals Used for Experimental and Other Scientific Purposes (Strasbourg, 1986).

\section{Deriving cell suspensions of bone marrow and lymph nodes}

Bone marrow donors, i.e. the $\mathrm{CBA} / \mathrm{H}$ mice were decapitated under light ether anesthesia. The bone marrow cells were washed out from the femur bones, and the inguinal lymph nodes were disintegrated in a Potter homogenizer in a handling medium (consisted of the medium 199 (Chumakov Institute of Poliomyelitis \& Viral Encephalites, Russia), 10\% fetal bovine serum (FBS) (BioloT, Russia) and 2\% sodium citrate (Weifang Ensign, China)); the resulted suspensions were passed then through a multi-layer nylon filter. The number of nucleated cells in the suspensions was counted in the Goryaev's chamber.

\section{GVHD induction}

GVHD was induced as follows. The (CBA/ HxC57B1)F1 mice were irradiated using RUM17 device (Mosrentgen, Russia) at a dose of 850 $\mathrm{R}$. The irradiation conditions were $38.6 \mathrm{R} / \mathrm{min}$ dose rate; $220 \mathrm{kV}$ voltage; $10 \mathrm{~mA}$ current; 0.5 $\mathrm{mm} \mathrm{Cu}+1 \mathrm{~mm} \mathrm{Al} \mathrm{filters;} 50 \mathrm{~cm}$ focus-dorsal distance. One hour later the irradiation the animals were injected into the tail vein with 0.2 $\mathrm{ml}$ of handling medium containing $5^{\prime} 10^{6}$ bone marrow cells together with the cells of lymph nodes of $\mathrm{CBA} / \mathrm{H}$ mice in 3:1 ratio [14].

As the control there were used intact mice (CBA/HxC57B1)F1, which were not irradiated and nothing was injected (intact control), and the irradiated mice (CBA/HxC57Bl)F1, which were administered with syngeneic bone marrow with the cells of inguinal lymph nodes $(3: 1)$ at the concentration of $5 \times 10^{6}$ cells/mouse (syngeneic control).

Isolation, culturing, and introduction of MSCs to the recipients with GVHD

To obtain MSCs the bone marrow cells of $\mathrm{CBA} / \mathrm{H}$ mice were isolated as described above and cultured in Iscove's Modified Dulbecco's Medium (Sigma-Aldrich, USA) supplemented with $10 \%$ fetal bovine serum, $50 \mathrm{IU} / \mathrm{ml}$ Penicillin, $50 \mathrm{IU} / \mathrm{ml}$ Streptomycin (growth medium); explantation density was $0.5-1 \times 10^{6}$ cells $/ \mathrm{cm}^{2}$; culture was performed in a $\mathrm{CO}_{2}$ - incubator (Barnstead International, USA) at $37^{\circ} \mathrm{C}$ with $5 \% \mathrm{CO}_{2} ; 3 \mathrm{~cm}$ glass Petri dish (Anumbra, $\mathrm{Czech}$ Republic) coated or non-coated with $\mathrm{Al}_{2} \mathrm{O}_{3}$ were used. The coatings were applied by magnetron sputtering method in a high vacuum pumping system [15]. After 24 hrs the non-adhered cells

were removed and an adhesive fraction was cultured till the subconfluent layer appearance; the growth medium was changed every 3 days. The cells were then detached with $0.25 \%$ Trypsin (Sigma-Aldrich, USA) and $0.02 \%$ EDTA (ICN, USA) solution according to the standard 
procedure [5]; enzyme was inactivated with a culture medium containing $10 \%$ FBS; cells were then washed and counted. Thereafter the MSCs were passaged with an explantation density of $0.5-1 \times 10^{4}$ cells $/ \mathrm{cm}^{2}$. Cell cultures were visually assessed using Axiovert 40C inverted microscope (Carl Zeiss, Germany).

After two passages the mesenchymal stem cells cultured either on a glass substrate (MSCg), or on a glass coated with an oxide nanocomposite, $\mathrm{Al}_{2} \mathrm{O}_{3}$ (MSCa) were detached, centrifuged for $10 \mathrm{~min}$ at $200 \mathrm{~g} / \mathrm{min}$, re-suspended in handling medium and intravenously injected at a dose of $2 \times 10^{5} /$ cells mouse 2 hrs after pathology induction.

Assessment of clinical and laboratory parameters before and after administration of MSCs to animals with GVHD

Body weight of the animals and their survival were assessed for 14 days after the induction of disease and administration of MSCs. There were 3 assessments, each group made from 7 to 11 animals. To day 14 the animals were decapitated under light ether anesthesia, and the spleen index and Treg content were evaluated as generally accepted.

Spleen index (SI) was calculated by the ratio of spleen to body weights of the animals. In intact animals the SI was assumed as equal to 1 ; the value higher than 1.3 indicated the GVHD development [14].

Treg content was analyzed in spleens of experimental and control animals. For this aim the spleens were disintegrated in a Potter homogenizer in a handling medium 199, then the suspensions were passed through a nylon filter. The content of cells with $\mathrm{CD} 4^{+} \mathrm{CD} 25^{+}$ and $\mathrm{FOXP}^{+}$phenotypes was assessed to day 14 after the administration of MSCs by FACS Calibur flow cytometer (Becton Dickinson, USA) using a panel of monoclonal anti-mouse antibodies: FOXP3 (PE) Nr. ab45122 (Abcam, England); CD4 (FITC) Nr. 553729 and CD25 (PE) Nr. 553075 (Becton Dickinson) according to the manufacturers' instructions. The control samples contained non-immune FITC or PE labelled monoclonal antibodies of the same antigen isotypes. Obtained cytofluorimetric data were statistically processed using the WinMDI 2.8 software (J. Trotter, The Scripps Research Institute, San Diego, CA, USA).

\section{Statistical analysis}

The obtained results were evaluated using the nonparametric Mann-Whitney test. . Statistical processing was performed using the Excel software (Microsoft, USA).

\section{RESULTS AND DISCUSSION}

One of important criteria of GVHD is splenomegaly, which intensity could be characterized with the splenic index (SI), referred also as the GVHD index [14]. As Fig. 1 shows, the SI was not significantly changed in the recipients of syngeneic bone marrow (syngeneic control) and was 1.4 times increased in animals with allomyelograft, that confirmed the GVHD development. Administering the MSCs to the animals with the induced pathology regardless of the substrate whereon they were cultured, resulted in a statistically significant reduction of SI value if compared to untreated animals. This reduction was mostly expressed in animals treated with MSCs grown on $\mathrm{Al}_{2} \mathrm{O}_{3}$ (MSCa). The index in these animals decreased to the level of the intact and syngeneic controls. This fact indicated that $\mathrm{Al}_{2} \mathrm{O}_{3}$ grown MSCs gained an additional immune modulating activity compared to those grown on non-coated glass (MSCg).

Treg lymphocytes, in particular firstly described by S. Sakaguchi et al. $\mathrm{CD} 4{ }^{+} \mathrm{CD} 25^{+}$ cells, play an important role in suppression of any form of immune aggression [16]. However, there is still no consensus about the concurrence of Treg pool and the cells with $\mathrm{CD} 4{ }^{+} \mathrm{CD} 25^{+}$and $\mathrm{FOXP}^{+}$phenotypes as well as manifestation of immune suppressive activity [17]. It is widely accepted that intracellular protein Foxp3 is the most specific Treg marker, determining their suppressor function. Nevertheless there is still 


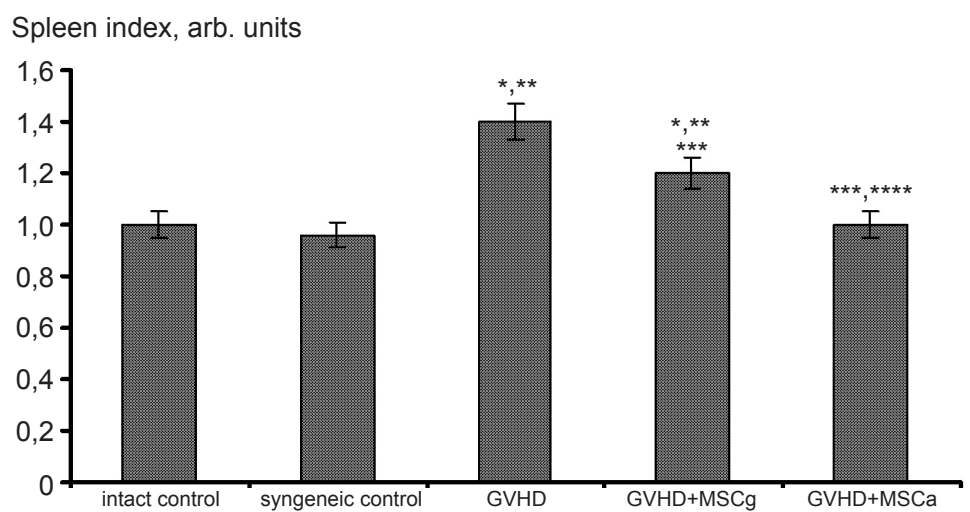

Fig. 1. Spleen index in recipients with GVHD before and after the injection of MSC grown on different substrates. The data are mean $\pm \mathrm{SD}$. The differences are statistically significant relative to intact control $(*)$; syngeneic control $(* *)$; group with GVHD $(* * *)$, between groups with injection of $\operatorname{MSC}(* * * *), \mathrm{P}<0.05$

the question if this marker is unique, and the screening for other marker molecules is ongoing.

Fig. 2 demonstrates that the indices of $\mathrm{FOXP}^{+}$and $\mathrm{CD}^{+}{ }^{+} \mathrm{CD} 25^{+}$cells in spleens of intact animals were close. In the recipients of syngeneic bone marrow the content of $\mathrm{CD} 4^{+} \mathrm{CD} 25^{+}$ cells did not statistically and significantly differ from intact control and that of $\mathrm{FOXP}^{+}$cells reduced in 1.2 times. This fact can testify about higher sensitivity of FOXP $3^{+}$cells to irradiation and bone marrow transplantation even if no immune conflict developed.

In the animals with developed GVHD the contents of $\mathrm{CD}^{+}{ }^{+} \mathrm{CD} 25^{+}$and $\mathrm{FOXP}^{+}$cells were correspondingly 1.5 and 2.1 times lower versus syngeneic control (Fig. 2). This was in accordance with the data of other scholars [10], demonstrated also the reducing Treg during GVHD development.

Application of MSCs cultured on non-coated glass significantly increased the content of $\mathrm{CD}^{+}{ }^{+} \mathrm{CD} 25^{+}$and $\mathrm{FOXP}^{+}$cells in the GVHD recipient spleens if compared with the indices of untreated animals $(\mathrm{P}<0.05)$. Moreover, the content of $\mathrm{CD} 4{ }^{+} \mathrm{CD} 25^{+}$cells even reached the control level. There was other situation after administering the MSCs cultured on $\mathrm{Al}_{2} \mathrm{O}_{3}$ nanocoating. In that case the MSCs demonstrated

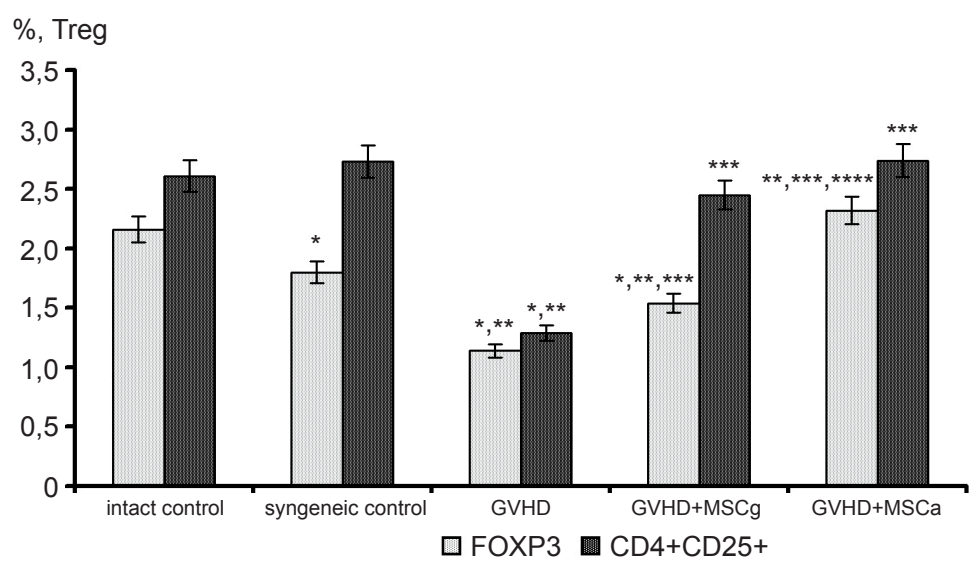

Fig. 2. Content of FOXP3+ and CD4+CD25+ cells in spleens of recipients with GVHD before and after injection of MSC grown on different substrates. The data are mean \pm SD. The differences are statistically significant relative to intact control $(*)$; syngeneic control $(* *)$; group with GVHD $(* * *)$, between groups with injection of MSC $(* * * *)$, $\mathrm{P}<0.05$ 
more profound stimulating effect for both Treg subpopulations: a significant increase was found in the content of both $\mathrm{CD} 4^{+} \mathrm{CD} 25^{+}$and $\mathrm{FOXP} 3^{+}$ cells (by 2.02 and 2.12 times, respectively, if compared with untreated animals). There was no significant differences in both indices from intact control, and the content of FOXP3 ${ }^{+}$ cells even exceeded the value of syngeneic control group $(\mathrm{P}<0.05)$. The concentration of $\mathrm{CD} 4{ }^{+} \mathrm{CD} 25^{+}$cells was 1.2 times higher than for FOXP3 + in this group of animals as well as in intact control. These results highlight the fact that although the two subpopulations with $\mathrm{CD} 4{ }^{+} \mathrm{CD} 25^{+}$and $\mathrm{FOXP} 3^{+}$phenotypes are considered as Treg their origin could be slightly different. The culture of MSCs on $\mathrm{Al}_{2} \mathrm{O}_{3}$ nanocoating provided their higher immune modulatory activity, including the activation of both studied Treg subpopulations.

One of the clinical signs of GVHD development in animals is a body weight reducing. In our case, this index in untreated animals was reduced by almost $30 \%$ by the end of the observation period (Fig. 3). Body weight in recipients of other groups decreased till day 7 and then increased. The most pronounced restoration of the index was found after introducing MSCa to the GVHD recipients: the intact control level was reached to the end of second week of observation.
Integral index of the GVHD severity is the survival of recipients (Fig. 4). The mass death of untreated animals began from day 4 after GVHD induction. Less than $25 \%$ of the animals survived to day 14 in the untreated group.

The severity of the immune conflict and consequent death of the animals in other groups depended on the type of MSCs used for treatment. Introduced MSCs grown on glass with $\mathrm{Al}_{2} \mathrm{O}_{3}$ coating showed an advantage over the non-coated-glass-grown MSCs: the survival rate of recipients with GVHD to day 14 following introduction was higher by 52 and $41.7 \%$ than in non-treated animals, respectively. Moreover, the first deaths in the animals which were transplanted with MSCa were observed only after day 11, while in animals treated with MSCg these were after day 7 . The survival rate in the group of animals with the introduced MSCa had no significant difference from the syngeneic control, that could show the minimization of immune conflict in this case. Indeed, the survival of the animals with GVHD after administration of both types of MSCs is in a line with the data characterizing the features of the Treg cell content (see Fig. 2). In particular, their more intensive formation in the MSCa treated group was accompanied by less pronounced loss of animals. To day 14 in the animals with MSCa higher percentage of Treg and evidently their activity

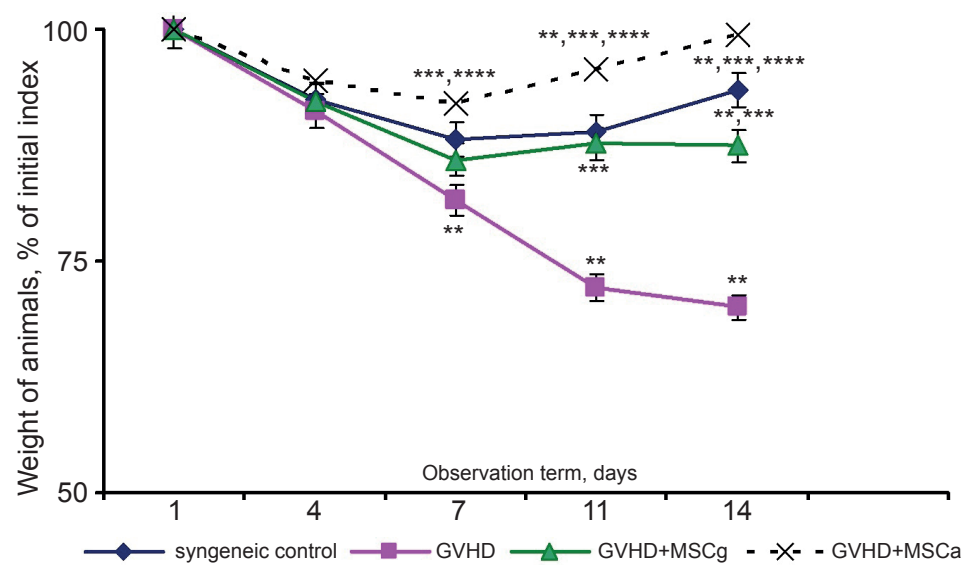

Fig. 3. Weight of animals with GVHD before and after injection of MSC, grown on different substrates. The data are mean \pm SD. The differences are statistically significant relative to intact control $(*)$; syngeneic control (**); group with GVHD (***), between groups with injection of $\operatorname{MSC}(* * * *), \mathrm{P}<0.05$ 


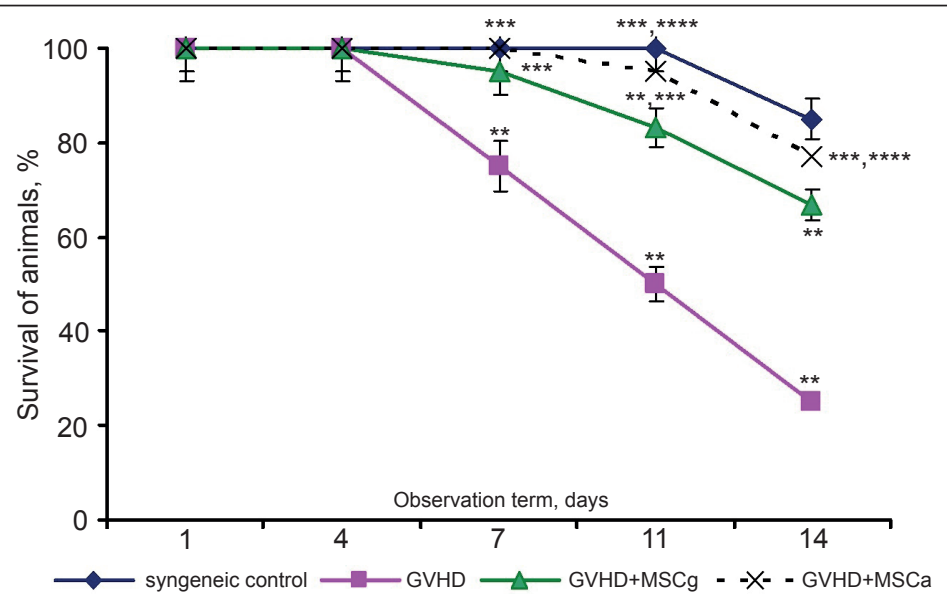

Fig. 4. Survival of animals with GVHD before and after treatment with MSC, grown on different substrates. The differences are statistically significant relative to intact control $(*)$; syngeneic control $(* *)$; GVHD with groups after MSC injection (***), between groups with injection of MSC $(* * * *), P<0,05$

in a greater extent suppress the effect of donor's immune competent cells while minimizing the animals' death in this group.

Disbalance in the content of regulatory cells during GVHD [17] in addition to the immune system disregulation causes hematopoietic disorders [18]. In this regard, it is important to search methodological approaches to minimize this pathology development. Previously we have experimentally confirmed the possibility of reducing the immune reactivity of allogeneic bone marrow by means of cryopreservation using certain protocols [19], which selectively altered the composition of the immune competent cell subpopulations and the whole state of myelotransplant. However, cryopreservation is known to reduce the hematopoietic potential of the transplant. An alternative to minimize the GVHD symptoms is co-transplantion of allogeneic bone marrow with cells possessing an immune modulating effect. Well-known is the immune modulating activity of MSCs $[4,8]$. In addition, fetal tissues were shown to have an immune regulatory activity. The ability of cryopreserved and non-frozen fetal liver and placenta cells to modulate the immune state of the animals with various types of experimental autoimmune diseases was demonstrated [20]. MSCs occurred to be the main part of these cells exhibiting such an activity. The adult MSCs are increasingly being used in clinical trials too [4]. Adult BM stroma contains a small amount of MSCs, which could be expanded in culture in vitro and reveal the ability to differentiate into osteo-, adipo- and chondrogenic directions [5]. About 10 years ago the MSCs grown in vitro were used for treatment of immune conflicts, particularly GVHD [5]. It was shown that the long-term in vitro culturing significantly reduced the multilinear differentiation and homing potential of MSCs [6].

To date, the sholars showed the possibility to control the functional state of cells by modifying the nanocomposite coated surfaces used for their culture [21,22]. Experiments in fibroblasts and macrophages grown on the matrix carriers (titanium and its alloys, niobium, stainless steel, polymers) showed an important role of material surface peculiarities (relief, hydrophobic and hydrophilic characteristics, chemical composition) which determine structural and functional characteristics of the cells [23]. Some researches were focused on the effect of a surface energy of different coatings, its dispersion and polar features rendered on cell cultures [24]. For example, high surface energy and coatings' fractional polarity were demonstrated to stimulate a fibroblast proliferation. Modification of 
the substrate surface ultrastructure entailed the development of the cascade of reactions leading to re-programming the intracellular signaling systems. The surface properties of biomaterials could influence gene expression [21]. The changes in expression of many genes involved into implementation of focal adhesion were found in osteoblasts, cultured on the titanium polymers with different surface; in particular, the genes encoding the growth factors, cytokines (TNF- $\alpha$, IL-1, IL-6); cell cycle and apoptotic processes were also affected. Kato S. et al. [25] reported the alterated gene expression of oncosupressor p53 and protooncogenes c-fos, c-myc, depending on the various hydrophobicity of biocoating surface.

Our preliminary studies for MSCs culturing involved the $\mathrm{Al}_{2} \mathrm{O}_{3}$ oxide coatings. Their application enabled to enrich during two passages the total bone marrow pool with the cells possessing MSCs markers, and the expression rate of ido gene transcripts in the cells as well $[13,26]$. These findings have confirmed the effect of the culture surface coating on MSCs' functional potential, in particular, the IDO production, determining an immune suppressive activity of these cells.

This research assessed an immune suppressive potential of $\mathrm{Al}_{2} \mathrm{O}_{3}$ oxide coating-grown MSCs using the GVHD model. Collectively, the application of the oxide nanocoating resulted in a rise of stimulating activity of MSCs in respect of T-regulatory immunity link of the recipient mice and reduced GVHD activity of allogeneic bone marrow.

The formation of Treg cells and manifestation of their suppressor function actively involve the transforming growth factor- $\beta$ (TGF- $\beta$ ) [27]. An important role here is played by the stromal stem elements, primarily by MSCs. Our previous findings showed a decrease in the expression rate of $\operatorname{tgf} \beta$ gene in the cells of recipient lymphohemopoietic complex during the local GVHD development [28]. This could be one of pathogenetically significant factors of this pathology development and the validate using of MSCs with determined functional potential in the therapy.

It is important to note that $\mathrm{Al}_{2} \mathrm{O}_{3}$ nanocoating-cultured MSCs had not only quantitative immune modulating features but gained also qualitative ones. Treatment of GVHD animals with the MSCs cultured on $\mathrm{Al}_{2} \mathrm{O}_{3}$ nanocoating unlike the non-coated glass had the effect of "harmonized" rise in the content of Treg subpopulations: $\mathrm{CD}^{+} \mathrm{CD} 25^{+}$and $\mathrm{FOXP}^{+}$cells. Exactly after introducing MSCs cultured on $\mathrm{Al}_{2} \mathrm{O}_{3}$ the GVHD severity decreased and the survival rate of animals significantly increased.

The obtained results could be the basis to develop the new approaches for improving the GVHD treatment using the nanocoating-cultured MSCs, purposefully altering their structural and functional properties.

\section{CONCLUSIONS}

Culturing of mesenchymal stromal cells in $\mathrm{Al}_{2} \mathrm{O}_{3}$ nanocoating contributes to an increase of their immune modulating activity.

Application of MSCs grown on $\mathrm{Al}_{2} \mathrm{O}_{3}$ nanocoating when treating the graft-versus-host disease (GVHD) in a greater extent than those grown on glass provide the rise of Treg cells in the recipients. In this case the severity of GVHD course has been shown to reduce that was manifested in an increased survival of the animals.

\section{Acknowledgments}

This work was supported by the STCU grant Nr. 4974.
А.Н. Гольцев ${ }^{1}$, И.В Paccoxa $^{1}$, Т.Г. Дубрава ${ }^{1}$, Л.В. Останкова ${ }^{1}$, М.В. Останков ${ }^{1}$, В.И. Сафонов ${ }^{2}$, А.В. Зыкова ${ }^{2}$
ЭКСПЕРИМЕНТАЛЬНАЯ ТЕРАПИЯ БОЛЕЗ- НИ «ТРАНСПЛАНТАТ ПРОТИВ ХОЗЯИНА» МЕЗЕНХИМАЛЬНЫМИ СТРОМАЛЬНЫМИ КЛЕТКАМИ, ВЫРАЩЕННЫМИ НА ОКСИД- НЫХ НАНОПОКРЫТИЯХ

Снижение иммуноагрессии аллогенного костного мозга в виде болезни «трансплантат против хозяина» (БТПХ) 
предусматривает необходимость подавления эффекторных и/или активации Т-регуляторных клеток (Treg). Экспериментально подтверждена возможность решения такой задачи путем совместной трансплантации с аллогенным костным мозгом мезенхимальных стромальных клеток (МСК). В нашей работе продемонстрировано повышение иммунокорригирующего эффекта МСК путем их культивирования in vitro на оксидном нанопокрытии $\mathrm{Al}_{2} \mathrm{O}_{3}$. При их введении животным с БТПХ наблюдалось увеличение содержания Treg в селезенке реципиентов костного мозга, снижение тяжести течения патологии, следствием чего было повышение выживаемости животных. Полученные результаты являются основанием для разработки новых подходов к оптимизации методов лечения БТПХ с помощью МСК, культивированных на оксидных нанопокрытиях.

Ключевые слова: нанопокрытия; мезенхимальные стромальные клетки; болезнь «трансплантат против хозяина».

${ }^{1}$ Институт проблем криобиологии и криомедицинь НАНУ, Харьков, е-mail: cryopato@gmail.com;

${ }^{2}$ Нацииональный научный изентр «Харьковский физикотехнический институт» НАНУ, Харьков.

\section{А.М. Гольцев ${ }^{1}$, І.В. Рaccoxa $^{1}$, Т.Г. Дубрава ${ }^{1}$, Л.В. Останкова ${ }^{1}$, М.В. Останков ${ }^{1}$, В.І. Сафонов ${ }^{2}$, А.В.Зикова ${ }^{2}$}

\section{ЕКСПЕРИМЕНТАЛЬНА ТЕРАПІЯ ХВОРО- БИ «ТРАНСПЛАНТАТ ПРОТИ ХАЗЯЇНА» МЕЗЕНХІМАЛЬНИМИ СТРОМАЛЬНИМИ КЛІТИНАМИ, ВИРОЩЕНИМИ НА ОКСИДНИХ НАНОПОКРИТТЯХ}

Зниження імуноагресії алогенного кісткового мозку у вигляді хвороби «трансплантат проти хозяїна» (ХТПХ) передбачає необхідність пригнічення ефекторних i / або активації Т-регуляторних клітин (Treg). Експериментально підтверджена можливість вирішення такого завдання за допомогою сумісної трансплантаціі з алогенним кістковим мозком мезенхімальних стромальних клітин (МСК). У нашій роботі продемонстровано підвищення імунокоригуючого потенціалу МСК їх культивуванням in vitro на оксидному нанопокритті $\mathrm{Al}_{2} \mathrm{O}_{3}$. При їх введенні тваринам 3 ХТПХ спостерігалося збільшення вмісту Treg у селезінці реципієнтів кісткового мозку, зниження важкості перебігу патології, наслідком чого було підвищення виживання тварин. Отримані результати є підставою для розробки нових підходів до оптимізації методів лікування ХТПХ за допомогою МСК, культивованих на оксидних нанопокриттях. Ключові слова: нанопокриття; мезенхімальні стромальні клітини; хвороба «трансплантат проти хозяїна»

\section{REFERENCES}

1. Shchepkina E A, Kruglyakov P V, Solomin L N, Zaritskiy Yu A, Nazarov V A, Viyde, et.al. Clinical experience with transplantation of autologous mesenchymal stem cells in the treatment of false joints of long bones. Trauma. 2007; 8 (3):22-30. [Russian].

2. Sullivan M P, McHale K L, Parvizi J, Mehta S. Nanotechnology: current concepts in orthopaedic surgery and future directions. Bone Joint J 2014; 96 (5): 569-73.

3. Webster T J. Nanomedicine: what's in a definition? Nanomedicine. Int J Nanomedicine. 2006; 1(2):169-76.

4. Le Blanc K, Samuelsson H, Gustafsson B, Remberger M, Sundberg B, Arvidson J. et.al. Transplantation of mesenchymal stem cells to enhance engraftment of hematopoietic stem cells. Leukemia. 2006; 21(8):1733-38.

5. Sergeev N S, Sviridov I K, Kirsanov V A, Akhmedova S A, Marshutina N V, Sergeev. In vitro study of parameters of the growth and differentiation of mesenchymal stromal cells of rat bone marrow in experiments in vitro. Cell Techn Biol Med. 2006;2: 102-7. [Russian].

6. Lee RH, Hsu SC, Munoz J, Jung JS, Lee NR. A subset of human rapidly-self renewing marrow stromal cells (MSCs) preferentially engraft in mice. Blood. 2006;107(5):2153-61.

7. Goltsev AN, Rassokha IV, Dubrava TG, Ostankova LV, Ostankov MV, Gordienko EA. et.al. Application of nanocomposite coatings for multipotent mesenchymal stromal cells cultivation technologies. Cell Transplantol Tis Engin. 2013;8(1):46-50. [Ukrainian].

8. Le Blanc K, Frassoni F, Ball L, Locatelli F, Roelofs H, Lewis I, et.al. Mesenchymal stem cells for treatment of steroid-resistant, severe, acute graft-versus-host disease: a phase II study. Lancet. 2008;371(9624):1579-86. PubMed PMID: 18468541.

9. Fallarino F, Grohmann U, You S, McGrath B.C, Cavener DR, Vacca C. et.al. The combined effects of tryptophan starvation and tryptophan catabolites down-regulate $\mathrm{T}$ cell receptor z-chain and induce a regulatory phenotype in naive T cells. J Immunol. 2006;176(11):6752-61.

10. Miura Y, Thoburn CJ, Bright EC, Phelps ML, Shin T, Matsui EC. et.al. Association of Foxp3 regulatory gene expression with graft-versus-host disease. Blood. 2004;104(7):2187-93.

11. Sándor S,Tamás K, Katalin M, Tibor T.G, Zoltán S, John V. Inhibition of indoleamine 2,3-dioxygenase-mediated tryptophan catabolism accelerates collagen-induced arthritis in mice. Arthr Res Ther. 2007 9:R50.

12. IDO-dependent immune modulating activity of cryopreserved fetal liver mesenchymal stem cells of mice in GVHR model Goltsev A., Dubrva T., Dimitrov A. Збірник Тез 4-го з'їзду Українського товариства клітинної біології $з$ міжнародним представництвом (17-20 вересня 2014, м.Ужгород), с. 83. [Ukrainian].

13. Safonov V, Zykova A, Smolik J, Rogovska R, Donkov N, Goltsev A et.al. Nanoscale biomaterial interface modifications for advanced tissue engineering applications. J Phys. 2012; Conf. Ser. 356:012046 doi: 10.1088/17426596/356/1/012046.

14. Shevelev, A.S. (1976) Graft versus host disease and transplantation disease. Moscow: "Meditsina". [Russian]. 
15. Donkov N, Zykova A, Safonov V, Smolik J, Rogowska R, Luk'yanchenko V. Formation of modern bearing surfaces by ceramic coating deposition for micro-bearing and biomedical applications. Rom Rep Phys. 2014;66(4):1180-8.

16. Sakaguchi S. Naturally arising Foxp3-expressing $\mathrm{CD} 25^{+} \mathrm{CD}^{+}$regulatory $\mathrm{T}$ cells in immunologica tolerance to self and non-self. Nat Immunol. 2005;(6): 345-52.

17. Yarilin AA. Natural regulatory T-cells and the factor FOXP3. Immunologiya. 2006;(3):176-88.

18. Hirohata S. Role of bone marrow in pathogenesis rheumatoid arthritis. Cur Rheum Rev. 2006;(12):47-54.

19. Goltsev AN, Lutsenko ED, Ostankova LV, Dubrava TG, Opanasenko EV. Application of cryobiology in solving immune-conflict problems when grafting a histocompatible bone marrow. Probl Cryobiol. 1996; (2):3-10. [Ukrainian].

20. Goltsev AN. Experimental research as substantiation of the possibility of stem cell therapy in clinical practice. Col. of papers "Survival strategy in the context of bioethics, philosophy and medicine". Moldova, Kishinev: "Meditsina". 2014; 20(4):224-7. [Ukrainian].

21. Ku CH, Browne M, Gregson PJ, Pioletti DP. Large-scale gene expression analysis of osteoblasts cultured on three different Ti-6AL-4V surface treatments. Biomaterials. 2002;23(21):4193-202.

22. Diener A, Nebe B, Uthen F, Becker P, Beck U, Neumann G. et.al. Control of focal adhesion dynamics by material surface characteristics. Biomaterials. 2005;26(4):383-92.

23. Deligaianni DD, Katsala ND, Koutsoukos PG, Missirlis
YF. Effect of surface roughness of hydroxyapatite on human bone marrow cell adhesion, proliferation, differentiation, and detachment strength. Biomaterials. 2001; 22 (1):87-96.

24. Zykova A, Safonov V, Virva O, Luk'yanchenko V, Walkowich J, Rogowska R. et.al. Surface parameters modification by multilayer coatings deposition for biomedical applications. J Phys Conf Ser. 2008; IOP Publishing. (113):15-9.

25. Kato S, Akagi T, Sugimura K, Kishida A, Akashi M. Evalution of biological responses to polymeric by RTPCR analysis IV: study of cmyc, c-fos and p53 mRNA expression. Biomaterials. 2000;(21):521 -7.

26. Goltsev AN, Rassokha IV, Dubrava TG, Ostankova LV, Ostankov MV, Gordienko. et.al. Application of nanocomposite coatings with different structural physical and chemical characteristics in tissue engineering. J Nan Electr Phys. 2013;5(1): 01008 (5pp).

27. Sugita S, Futagami Y, Hori S, Mochizuki M. Transforming growth factor producing $\mathrm{FoxP} 3{ }^{+} \mathrm{CD} 4{ }^{+} \mathrm{CD} 25^{+} \mathrm{T}$ cells by iris pigment epithelial cells display regulatory phenotype and acquire regulatory functions. Exp res. 2007;85(5):626-36.

28. Goltsev AN, Dubrava TG, Lutsenko ED, Ostankova LV, Matsevitaya IYu, Ostankov V. et.al. Manifestation of immune correcting effect of cryopreserved cells of fetal liver of different gestation terms under development conditions of experimental model of graft versus host reaction. Cel transplant tis engineer. 2010;5(3):82-6. [Ukrainian]. 